JURNAL PENDIDIKAN, p-ISSN 2715-095X, e-ISSN 2686-5041

Volume 29, No.1, Maret 2020 (67-76)

Online: http://journal.univetbantara.ac.id/index.php/ JP

\title{
Peningkatan Aktivitas dan Hasil Belajar Matematika Materi Barisan dan Deret Melalui Pendekatan SAVI Bagi Siswa Kelas XI IPS1 SMA Negeri 1 Tawangsari Semester 2 Tahun Pelajaran 2018/2019
}

\begin{abstract}
Suratno
Guru SMA Negeri 1 Tawangsari Kabupaten Sukoharjo, email: suratnoratno9898@gmail.com

Abstrak: Penelitian ini merupakan Penelitian Tindakan Kelas, yang bertujuan untuk aktivitas dan hasil belajar melalui pendekatan pembelajaran Somatis, Auditori, Visual, Intelektual. Subyek penelitian adalah siswa kelas XI IPS1 SMA Negeri 1 Tawangsari semester 2 yang berjumlah 36 siswa. Teknik pengumpulan data dengan menggunakan metode tes tertulis, observasi, dokumentasi. Adapun prosedur penelitian dilakukan melalui dua siklus dan setiap siklus terdiri dari perencanaan, pelaksanaan, observasi dan refleksi. Hasil penelitian: (1) terjadi peningkatan aktivitas belajar siswa bila dibandingkan antara prasiklus yaitu nilai rata-rata 1,86 (kurang) di akhir siklus 2 menjadi 4,03 (baik); (2) terjadi peningkatan pencapaian ketuntasan belajar siswa bila dibandingkan antara prasiklus yaitu 6 siswa $(25 \%)$ di akhir siklus 2 menjadi 31 siswa $(91,67 \%)$ sehingga sudah mencapai tingkat ketuntasan sebagaimana telah ditetapkan yaitu $\geq 85 \%$. Terjadi peningkatan pencapaian nilai rata-rata bila dibandingkan antara prasiklus 57,11 di akhir siklus 2 menjadi 83,61. Simpulan penelitian ini bahwa penerapan pendekatan SAVI dapat meningkatkan aktivitas siswa dan hasil belajar matematika materi barisan dan deret.
\end{abstract}

Kata-kata Kunci: Aktivitas, Hasil Belajar, Pendekatan Somatis, Auditori, Visual, Intelektual

Improvement of Activities and Learning Outcomes of Mathematics in Row and Series Material Through the SAVI Approach for Class XI IPS1 Students of SMA Negeri 1 Tawangsari Semester 2 for 2018/2019 Academic Year

\section{Suratno}

Teacher of SMA Negeri 1 Tawangsari, Sukoharjo Regency, email: suratnoratno9898@gmail.com

\begin{abstract}
This research is a Classroom Action Research, which aims at learning activities and outcomes through a Somatic, Auditory, Visual, Intellectual Learning approach. The research subjects were students of class XI IPS1 of SMA Negeri 1 Tawangsari in semester 2 of 36 students. Data collection techniques using the method of written tests, observations, documentation. The research procedure is carried out through two cycles and each cycle consists of planning, implementation, observation and reflection. The results of the study: (1) an increase in student learning activities when compared between pre-cycles ie an average value of 1.86 (less) at the end of cycle 2 to 4.03 (good); (2) there was an increase in students' mastery learning achievement when compared between pre-cycles, namely 6 students (25\%) at the end of cycle 2 to 31 students $(91.67 \%)$ so that they had reached the level of mastery as set that is $\geq 85 \%$. An increase in the achievement of the average value when compared between pre-cycle 57.11 at the end of cycle 2 to 83.61. The conclusion of this research is that the application of the SAVI approach can improve student activity and mathematics learning outcomes of sequential and sequence material.
\end{abstract}

Keywords: Activity, Learning Outcomes, Somatic Approach, Auditory, Visual, Intellectual 


\section{Pendahuluan}

Rendahnya aktivitas hasil belajar matematika materi barisan dan deret disebabkan guru masih menerapkan pendekatan pembelajaran yang bersifat konvensional dan suasana kelas cenderung teacher centered sehingga siswa menjadi pasif. Guru lebih suka menerapkan pendekatan tersebut karena tidak memerlukan media belajar, alat peraga, dan bahan praktik, tetapi hanya menjelaskan konsep-konsep yang ada pada buku ajar atau referensi lain. Dalam hal ini, siswa tidak diajarkan bagaimana belajar untuk mengalami dan melakukan (somatic), mendengarkan (auditory), menggunakan indera (Visualization), dan menggunakan kemampuan berfikir (Intellectualy) padahal aspek-aspek tersebut merupakan kunci keberhasilan dalam suatu pembelajaran. Rendahnya aktivitas siswa ditandai sebagian besar bersikap pasif dalam mengikuti pembelajaran matematika. Rendahnya hasil belajar ditandai sulitnya pencapaian batas ketutasan belajar minimal yang telah ditetapkan sekolah (70). Berdasarkan tes kemampuan awal yang dilaksanakan pada hari kamis tanggal 7 Januari 2019diperoleh hasil sebagai berikut: 9 siswa (25\%) yang mendapat nilai diatas KKM dan 27 siswa (75 \%) yang mendapat nilai di bawah KBM, nilai rata-rata 57,11 nilai tertinggi 87 dan nilai terendah 26. Selanjutnya berdasarkan hasil pengamatan terhadapat aktivitas siswa dalam mengikuti pembelajaran diperoleh hasil sebagai berikut: 6 siswa (16,67 \%) mendapat nilai baik , 3 siswa (8,33\%) memiliki nilai cukup; 7 siswa (19,44\%) memiliki nilai sedang; 20 siswa $(55,56 \%)$ memiliki nilai kurang. Untuk menyelesaikan permasalahan di atas dibutuhkan solusi yang tepat dan sistematis karena jika terus dibiarkan maka pembelajaran pada materi barisan dan deret tidak akan bermakna bagi siswa dan semakin banyak yang tidak menyukai mata pelajaran matematika. Sebagai solusinya adalah menerapkan pendekatan pembelajaran "SAVI" (Somatis, Auditori, Visual, Intelektual) karena pendekatan ini melibatkan aktivitas fisik dan intelektual dalam pembelajaran. yang dapat membuat siswa aktif dan kreatif. Meier (2002: 100) menegaskan bahwa "Belajar bisa optimal jika keempat unsur "SAVI" ada dalam satu peristiwa pembelajaran." Dengan pendekatan "SAVI" siswa dapat melibatkan seluruh indranya dalam pembelajaran dan juga dapat mengaktifkan intelektualnya. Jadi, tubuh dan otak sama-sama berperan dalam pembelajaran dengan harapan hasil pembelajaran dapat maksimal. Dari permasalahan di atas, peningkatan aktivitas dan hasil belajar matematika materi barisan dan deret bagi kelas XI IPS1 SMA Negeri 1 Tawangsari semester 2 tahun pelajaran 2018/2019 adalah menerapkan pendekatan "SAVI". Penerapan pendekatan "SAVI" diharapkan dapat menciptakan suasana pembelajaran yang aktif, kreatif, efektif, dan menyenangkan sehingga terjadi peningkatan aktivitas dan hasil belajar matematika materi barisan dan deretAktivitas adalah kegiatan yang dilakukan seseorang dalam tiap bagian di dalam suatu pekerjaan. Aktivitas juga bisa diartikan keaktifan dalam melakukan sesuatu. Lebih lanjut aktif adalah giat bekerja atau berusaha. Dengan demikian aktivitas adalah kegiatan yang dilakukan seseorang dalam bekerja atau berusaha untuk mencapai sesuatu tujuan. Aktivitas belajar adalah kegiatan yang dilakukan siswa dalam mempelajari materi pembelajaran untuk mencapai atau mendapatkan hasil (nilai) yang ditentukan.

Menurut Sriyono (2008) aktivitas adalah segala kegiatan yang dilaksanakan baik secara jasmani atau rohani. Aktivitas siswa selama proses belajar mengajar merupakan salah satu indikator adanya keinginan siswa untuk belajar. Aktivitas siswa merupakan kegiatan atau perilaku yang terjadi selama proses belajar mengajar. Kegiatan-kegiatan yang dimaksud adalah kegiatan yang mengarah pada proses belajar seperti bertanya, mengajukan pendapat, mengerjakan tugas-tugas, dapat menjawab pertanyaan guru dan bisa bekerjasama 
dengan siswa lain, serta tanggung jawab terhadap tugas yang diberikan. Setiap siswa mempunyai kemampuan belajar berbeda-beda, kemampuan tersebut diantaranya dapat dilihat dari aktivitas belajarnya. Aktivitas belajar didefinisikan sebagai suatu proses perubahan dalam sikap atau tingkah laku. Pendapat lain dikatakan bahwa aktivitas belajar adalah belajar yang tergantung akan kebutuhan, motivasi dan sikap tertentu untuk mencapai tujuan. (Hamalik; 1999: 4). Hasil belajar sering orang menyebutnya prestasi belajar. Menurut Winkel, prestasi adalah bukti keberhasilan usaha yang dicapai (Winkel, 1986: 162). Hasil belajar adalah penguasaan pengetahuan/keterampilan yang dikembangkan oleh mata pelajaran yang biasanya ditunjukkan dengan nilai tes atau angka yang diberikan guru.Hasil belajar merupakan hal yang penting yang akan dijadikan sebagai tolok ukur keberhasilan siswa dalam belajar dan sejauh mana sistem pembelajaran yang diberikan guru berhasil atau tidak. Suatu proses belajar mengajar dikatakan berhasil apabila kompetensi dasar yang diinginkan tercapai. Untuk mengetahui tercapai tidaknya kompetensi tersebut, guru mengadakan tes setelah menyajikan materi pembelajaran kepada siswa. Dari hasil tes ini diketahui sejauh mana keberhasilan siswa dalam belajar.

Paradigma guru terhadap pembelajaran dapat tercermin dari pemilihan pendekatan yang digunakan. Pendekatan pembelajaran yang diterapkan akan mempengaruhi tercapainya tujuan pembelajaran. Oleh karena itu, guru perlu memilih pendekatan yang tepat agar tujuan pembelajaran dapat tercapai dengan optimal. Menurut Wina Sanjaya (2006: 127) "Pendekatan dapat diartikan sebagai titik tolak atau sudut pandang kita terhadap proses pembelajaran. Istilah pendekatan merujuk kepada pandangan tentang terjadinya suatu proses yang sifatnya masih sangat umum." Sejalan dengan pendapat tersebut, T. Raka Joni dalam Soli Abimanyu, dkk (2008: 2.4) menyatakan bahwa "Pendekatan adalah cara umum dalam memandang permasalahan atau obyek kajian, sehingga berdampak ibarat seseorang menggunakan kacamata dengan warna tertentu didalam memandang alam." Dari beberapa pengertian mengenai pendekatan pembelajaran di atas dapat disimpulkan, pendekatan adalah cara atau sudut pandang guru yang bersifat umum terhadap proses pembelajaran. Sebelum melaksanakan pembelajaran guru perlu memilih pendekatan yang akan diterapkan, yaitu menentukan kegiatan pembelajaran yang akan dilaksanakan secara keseluruhan. Dalam kegiatan pembelajaran tersebut memunculkan penggunaan metode-metode yang mendukung pendekatan yang diterapkan guru. Pendekatan SAVI termasuk pendekatan pembelajaran yang berpusat pada siswa (student centered approach) yaitu pendekatan yang menekankan keterlibatan siswa dalam pembelajaran. Teori yang mendukung pendekatan SAVI adalah Accelarated Learning. Meier (2002: 38) menjelaskan bahwa "Accelerated learning adalah pembelajaran yang alamiah, yang didasarkan pada cara orang belajar secara alamiah." Berdasarkan landasan teori di atas, maka dapat dirumuskan hipotesis tindakan kelas sebagai berikut: penerapan pendekatan pembelajaran SAVI dapat meningkatkan aktivitas dan hasil belajar matematika kelas XI IPS1 SMA Negeri 1 Tawangsari semester 2 tahun pelajaran 2018/2019.

\section{Metode Penelitian}

Prosedur penelitian adalah sebuah rangkaian tahap penelitian dari awal hingga akhir. Menurut Suharsimi Arikunto (2008: 16) ada empat tahapan penting dalam penelitian tindakan yaitu: (1) perencanaan (planning); (2) penerapan tindakan (action); (3) mengobservasi (observation); dan (4) melakukan refleksi (reflecting). Penelitian ini dilaksanakan di SMA Negeri 1 Tawangsari. Penelitian ini dilakukan selama selama 5 bulan yaitu mulai bulan Januari sampai dengan Mei 2019. Peneliti juga sebagai observer yaitu guru SMA Negeri 1 Tawangsari mata pelajaran matematika. Subyek dari penelitian 
tindakan kelas ini adalah kelas XI IPS1 SMA Negeri 1 Tawangsari pada semester 2 tahun pelajaran 2018/2019 dengan jumlah siswa 36 terdiri dari 11 laki-laki dan 25perempuan. Teknik pengumpulan data yang digunakan adalah: tes, observasi, dan dokumentasi. Menurut Nurkancana dan Sumartana dalam Sarwiji Suwandi (2009: 39) tes adalah suatu cara untuk melakukan penilaian yang berbentuk tugas-tugas yang harus dikerjakan siswa untuk mendapatkan data tentang nilai dan prestasi siswa tersebut yang dapat dibandingkan dengan yang dicapai kawan-kawan atau nilai standar yang ditetapkan.Dilihat dari bentuknya, tes dapat dibedakan menjadi tes subjektif (essay) dan tes objektif (short answer test), yang terdiri dari tes jawaban benar salah (true-false), pilihan ganda (multiple choice), isian singkat (completion), dan penjodohan (matching) (Sarwiji Suwandi, 2009: 48). Tes dalam penelitian ini akan dilaksanakan setiap akhir siklus sebagai evaluasi. Pemberian tes dimaksudkan untuk mengukur seberapa tinggi penguasaan materi barisan dan deret bagi siswa kelas XI IPS1 SMA Negeri 1 Tawangsari pada semester 2 setelah tindakan menggunakan pendekatan SAVI.Observasi atau pengamatan adalah kegiatan yang meliputipemusatan perhatian terhadap suatu objek dengan menggunakan sebuah alat indera. Observasi dapat dilakukan dengan dua cara : Observasi non sistematis, yang dilakukan oleh pengamat dengan tidak menggunakan instrumen pengamatan. Observasi sistematis, yang dilakukan oleh pengamat dengan menggunakan pedoman sebagai instrumen pengamatan. Dalam penelitian ini, observasi yang dilakukan adalah observasi sistematis. Pedoman pengamatan yang digunakan untuk menggambarkan proses pembelajaran yang dilaksanakan oleh guru, situasi dan kondisi kelas serta sikap siswa adalah catatan harian guru, lembar observasi guru dan lembar observasi siswa. Teknik mencatat dokumen oleh Yin dalam H.B. Sutopo (2002: 69) disebut sebagai content analysis, sebagai cara untuk menemukan beragam hal sesuai dengan kebutuhan dan tujuan penelitiannya. Sugiyono (2009: 329) mengungkapkan bahwa "Dokumen merupakan catatan peristiwa yang sudah berlalu. Dokumen bisa berbentuk tulisan, gambar, atau karya-karya monumental dari seseorang."Data dokumentasi digunakan untuk memperoleh berbagai arsip yang diperlukan dalam penelitian ini, seperti Silabus dan Rencana Pelaksanaan Pembelajaran (RPP) matematika kelas XI IPS1.Foto yang diambil adalah pada saat peneliti melaksanakan pembelajaran setiap siklus yang digunakan untuk memperkuat data yang diperoleh. Dokumentasi foto kegiatan pembelajaran, merupakan instrumen yang penting karena sebagai bukti kegiatan yang dilaksanakan selama penelitian. Rekaman selama kegiatan pelaksanaan pembelajaran juga dapat dilihat kembali oleh peneliti untuk mengkroscekkan data yang diperoleh. Adapun dokumen foto yang diambil adalah pada saat guru atau peneliti melaksanakan pembelajaran setiap siklus.Teknik analisis data yang digunakan dalam penelitian ini adalah model analisis interaktif. Cara analisisnya mengikuti pola pemikiran yang kongkret kualitatif artinya suatu analisis yang kajiannya didasarkan pada kenyataan-kenyataan empirik dan unsur-unsur terkecil dari pendekatan secara mikro ke makro untuk unit kasus tertentu.Model analisis interaktif mempunyai tiga komponen yaitu: (1) Reduksi Data (Data Reduction), (2) Penyajian Data (Data Display), (3) Penarikan Kesimpulan (Verification). Miles dan Huberman (2009: 19) mengemukakan bahwa tiga komponen tersebut sebagai sesuatu yang jalin menjalin pada saat sebelum, selama, dan sesudah pengumpulan data dalam bentuk yang sejajar, untuk membangun wawasan umum yang disebut analisis. Reduksi data, penyajian data, dan penarikan kesimpulan menjadi gambaran keberhasilan secara berurutan sebagai rangkaian kegiatan analisis yang saling susul menyusul. Berikut penjelasan alur kegiatan analisis interaktif menurut Miles dan 
Huberman (2009: 15-21). Ketiga komponen analisis data saling berhubungan dan dapat digambarkan pada gambar 2 berikut. Menurut Sarwiji Suwandi (2009: 61) "Indikator kinerja merupakan rumusan kinerja yang akan dijadikan acuan atau tolak ukur dalam menentukan keberhasilan/keefektifan penelitian." Indikator kinerja yang ingin dicapai dalam penelitian ini adalah meningkatnya aktivitas dan hasil belajar matematika materi barisan dan deret bagi siswa kelas XI IPS1 SMA Negeri 1 Tawangsari pada semester 2 kabupaten Sukoharjo setelah menerapkan pendekatan SAVI. Indikator penelitian ini mencakup dua macam keberhasilan yaitu keberhasilan produk (kuantitatif) dan keberhasilan proses (kualitatif). Indikator kuantitatif merupakan keberhasilan produk penelitian yang diketahui dari hasil tes di akhir tiap siklus. Keberhasilan produk dibedakan menjadi dua yaitu keberhasilan individual dan keberhasilan klasikal. Keberhasilan individual apabila siswa dinyatakan telah berhasil secara individual jika nilai yang diperoleh dari hasil tes lebih dari atau sama dengan nilai Kriteria Ketuntasan Minimal (KKM) yaitu sebesar 70, serta nilai yang diperoleh dari tes di akhir siklus 1 ke siklus 2 mengalami peningkatan. Sedangkan keberhasilan klasikal/kelas ditunjukkan oleh semakin banyaknya siswa yang mencapai nilai $85 \% \geq$ KKM yaitu sebesar 70 .

\section{Hasil Penelitian}

Berdasarkan tes kemampuan awal yang dilaksanakan pada hari kamis tanggal 7 Januari 2019 diperoleh hasil sebagai berikut: 9 siswa $(25 \%)$ yang mendapat nilai diatas KKM dan 27 siswa (75\%) yang mendapat nilai di bawah KBM, nilai rata-rata 57,11 nilai tertinggi 87 dan nilai terendah 26. Selanjutnya berdasarkan hasil pengamatan terhadap aktivitas siswa dalam mengikuti pembelajaran diperoleh hasil sebagai berikut: 6 siswa (16,67\%) mendapat nilai baik , 3 siswa (8,33\%) memiliki nilai cukup; 7 siswa $(19,44 \%)$ memiliki nilai sedang; 20 siswa (55,56 \%) memiliki nilai kurang. Berdasarkan data tersebut masih banyak siswa yang belum memperoleh nilai di atas KKM yang telah ditentukan yaitu 70. Sebagaimana prosentase ketuntasan yang telah ditetapkan adalah $85 \%$. Diharapkan pada siklus 1 ketuntasan klasikal akan mengalami kenaikan. Pada siklus 1, nilai rata-rata penguasaan materi barisan dan deret aritmatika sebesar 73,89 dengan nilai tertinggi 100 dan nilai terendah 42, serta ketuntasan belajar 66,67 \%. Ketuntasan klasikal pada akhir siklus 1 ini mencapai 66,67 \% (24 siswa), sedangkan masih ada 12 siswa (23,33 \%) yang belum tuntas, sehingga perlu tindakan pada siklus berikutnya dengan beberapa perbaikan. Sedangkan berdasarkan observasi aktivitas belajar siswa, nilai rata-rata aktivitas belajar siswa adalah 3,11 (cukup), sehingga mengalami peningkatan sebesar 1,24. Dengan persebaran sebagai berikut; siswa yang memperoleh nilai sangat baik sekali sebanyak 6 siswa atau 23,08 \%. Siswa yang memperoleh nilai baik sebanyak 8 siswa atau 30,77\%. Siswa yang memperoleh nilai cukup sebanyak 11 siswa atau 42,31\%. Siswa yang memperoleh nilai sedang sebanyak 1 siswa atau 3,85\%. Siswa yang memperoleh nilai kurang sebanyak 0 siswa atau $0 \%$.

Tabel 1. Perbandingan Hasil Belajar siswa Kondisi Antara Pra Siklus dan siklus 1

\begin{tabular}{llrrr}
\hline No & Rentang nilai & $\begin{array}{l}\text { Frekuensi } \\
\text { Prasiklus }\end{array}$ & $\begin{array}{l}\text { frekuensi } \\
\text { Siklus 1 }\end{array}$ & Selisih \\
\hline 1 & Rata-rata & 57,11 & 73,89 & 16,78 \\
2 & Nilai Tertinggi & 87 & 100 & 13 \\
3 & Nilai Terendah & 26 & 42 & 16 \\
4 & Mencapai KKM & 25 & 66,67 & 41,67 \\
5 & Belum Mencapai & 75 & 33,33 & 41,67 \\
\hline
\end{tabular}


KKM

Tabel 2. Perbandingan Aktivitas Belajar siswa Kondisi Antara Pra Siklus dan siklus 1

\begin{tabular}{clrrrrr}
\hline \multirow{2}{*}{ No } & \multirow{2}{*}{ Kriteria } & \multicolumn{2}{c}{ Prasiklus } & \multicolumn{2}{c}{ Siklus 1 } & Selisih \\
& & Jumlah & Pesentase & Jumlah & Pesentase & \multicolumn{1}{c}{$(\%)$} \\
\hline 1 & Baik Sekali & 0 & 0,00 & 6 & 16,67 & 16,67 \\
2 & Baik & 6 & 16,67 & 8 & 22,22 & 5,56 \\
3 & Cukup & 3 & 8,33 & 13 & 36,11 & 27,78 \\
4 & Sedang & 7 & 19,44 & 5 & 13,89 & 5,56 \\
5 & Kurang & 20 & 55,56 & 4 & 11,11 & 44,44 \\
\hline
\end{tabular}

Siklus 2 merupakan kelanjutan dari siklus 1 yang mana pada siklus 1 belum mencapai indikator yang telah ditetapkan yaitu ketuntasan klasikal $\geq 85 \%$. Hasil akhir yang diperoleh pada siklus 1 di pakai sebagai acuan dalam melaksanakan siklus 2. Pada siklus 2, nilai rata-rata kelas sebesar 83,61 dengan nilai tertinggi 100 dan nilai terendah 45 , serta ketuntasan klasikal 91,67\%. Ketuntasan klasikal pada akhir siklus 2 ini mencapai 91,67\% (31 siswa), sedangkan masih ada 5 siswa (8,33 \%). Sedangkan berdasarkan observasi aktivitas belajar siswa, nilai rata-rata aktivitas belajar siswa adalah 4,03 ( baik), sedangkan pada siklus 1 rata-ratanya adalah 13,11, sehingga mengalami peningkatan sebesar 0,92 . Dengan persebaran sebagai berikut; siswa yang memperoleh nilai sangat baik sekali sebanyak 13 siswa atau 36,11\%. Siswa yang memperoleh nilai baik sebanyak 17 siswa atau $47,22 \%$. Siswa yang memperoleh nilai cukup sebanyak 1 siswa atau $2,78 \%$. Siswa yang memperoleh nilai sedang sebanyak 4 siswa atau $11,11 \%$. Siswa yang memperoleh nilai kurang sebanyak 1 siswa atau 2,78\%. Pada siklus 2 ini mengalami peningkatan prosentasi aktivitas dan hasil belajar siswa. Untuk mengetahui perbandingan rata-rata aktivitas dan hasil belajar siswa disajikan dalam tabel berikut.

Tabel 3. Perbandingan Hasil Belajar Siswa Kondisi Siklus 1 dan Siklus 2

\begin{tabular}{clrrr}
\hline \multirow{2}{*}{ No } & \multirow{2}{*}{ Rentang nilai } & frekuensi & frekuensi & \multirow{2}{*}{ Selisih } \\
& & Siklus 1 & Siklus & \\
\hline 1 & Rata-rata & 73,89 & 83,61 & 9,72 \\
2 & Nilai Tertinggi & 100 & 100 & 0 \\
3 & Nilai Terendah & 42 & 45 & 3 \\
4 & Mencapai KKM & 66,67 & 91,67 & 25 \\
5 & Belum Mencapai KKM & 33,33 & 8,33 & 25 \\
\hline
\end{tabular}

Tabel 4. Perbandingan Aktivitas Belajar Siswa Kondisi Siklus 1 dan Siklus 2

\begin{tabular}{llrrrrr}
\hline \multirow{2}{*}{ No } & & \multicolumn{2}{c}{ Siklus 1 } & \multicolumn{2}{c}{ Siklus 2 } & Selisih \\
& & Jumlah & Pesentase & Jumlah & Pesentase & \multicolumn{1}{c}{$(\%)$} \\
\hline 1 & Baik Sekali & 1 & 2,78 & 13 & 36,11 & 33,33 \\
2 & Baik & 16 & 44,44 & 17 & 47,22 & 2,78 \\
3 & Cukup & 7 & 19,44 & 1 & 2,78 & 16,67 \\
4 & Sedang & 10 & 27,78 & 4 & 11,11 & 11,11 \\
5 & Kurang & 2 & 5,56 & 1 & 2,78 & 2,78 \\
\hline
\end{tabular}

Guru merencanakan pelaksanaan penelitian sebanyak 2 siklus. Kegiatan di mulai dari prasiklus, yang dilanjutkan dengan siklus 1 dan di akhiri dengan siklus 2. Hasil dari tindakan siklus 1 dijadikan peneliti sebagai acuan untuk melaksanakan siklus 2. Pada 
pelaksanaan kegiatan pembelajaran siklus 2 ini masih sama dengan pelaksanaan pada siklus 1 yaitu karena pada siklus 1 sudah menunjukkan peningkatan yang signifikan. Peningkatan ini tidak saja pada rat-rata nilai siswa saja tetapi juga peningkatan persentasi ketuntasan klasikal, termasuk juga peningkatan aktivitas belajarnya. Untuk memperjelas perbandingan peningkatan aktivitas dan hasil belajar siswa antara prasiklus, siklus 1 dan siklus 2 secara lebih lengkap dapat dilihat pada tabel dan grafik berikut ini.

Tabel 5. Perbandingan Hasil Belajar Antara Prasiklus, Siklus 1 dan Siklus 2

\begin{tabular}{rlrrrrrr}
\hline \multirow{2}{*}{ No } & \multirow{2}{*}{ Kriteria } & \multicolumn{2}{c}{ Prasiklus } & \multicolumn{2}{c}{ Siklus 1 } & \multicolumn{2}{c}{ Siklus 2 } \\
& & \multicolumn{3}{c}{ Jumlah Pesentase Jumlah Pesentase } & Jumlah & Pesentase \\
\hline 1 & Baik Sekali & 1 & 3,85 & 6 & 23,08 & 9 & 34,62 \\
2 & Baik & 6 & 23,08 & 8 & 30,77 & 12 & 46,15 \\
3 & Cukup & 11 & 42,31 & 11 & 42,31 & 5 & 19,23 \\
4 & Sedang & 7 & 26,92 & 1 & 3,85 & 0 & 0,00 \\
5 & Kurang & 1 & 3,85 & 0 & 0,00 & 0 & 0,00 \\
\hline
\end{tabular}

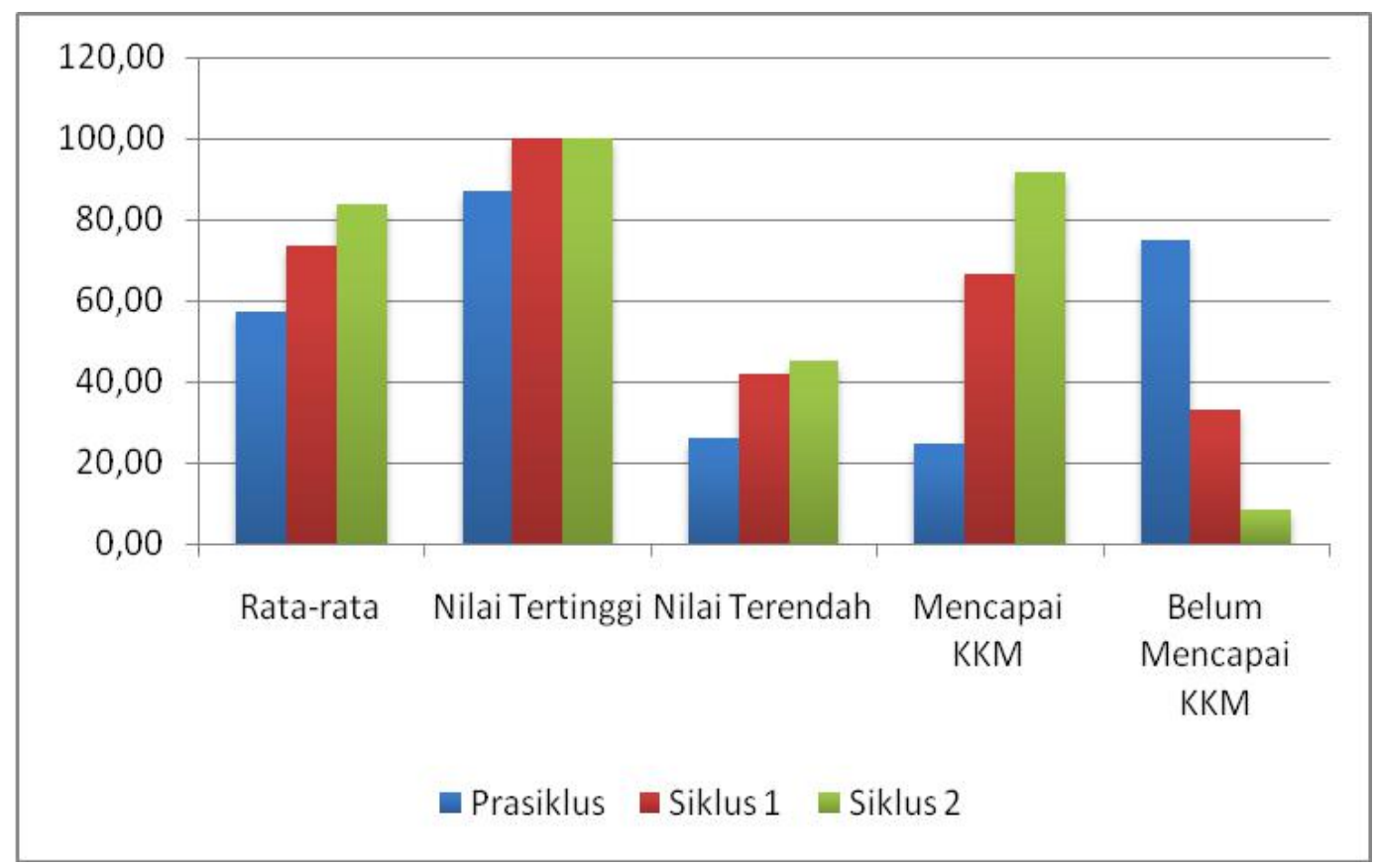

Grafik 1. Perbandingan Hasil Belajar Antara Prasiklus, Siklus 1 dan Siklus 2

Tabel 6 Perbandingan Aktivitas Belajar Siswa Antara Prasiklus, Siklus 1,dan Siklus 2

\begin{tabular}{rlrrr}
\hline No & \multicolumn{1}{c}{ Uraian } & $\begin{array}{c}\text { Prasiklus } \\
(\%)\end{array}$ & $\begin{array}{c}\text { Siklus } \\
1(\%)\end{array}$ & \multicolumn{1}{c}{$\begin{array}{c}\text { Siklus 2 } \\
(\%)\end{array}$} \\
\hline 1 & Rata-rata & 57,11 & 73,81 & 83,69 \\
2 & Nilai Tertinggi & 87 & 100 & 100 \\
3 & Nilai Terendah & 26 & 42 & 45 \\
4 & Mencapai KBM & 25 & 66,67 & 91,67 \\
5 & Belum Mencapai KBM & 75 & 33,33 & 8,33 \\
\hline
\end{tabular}




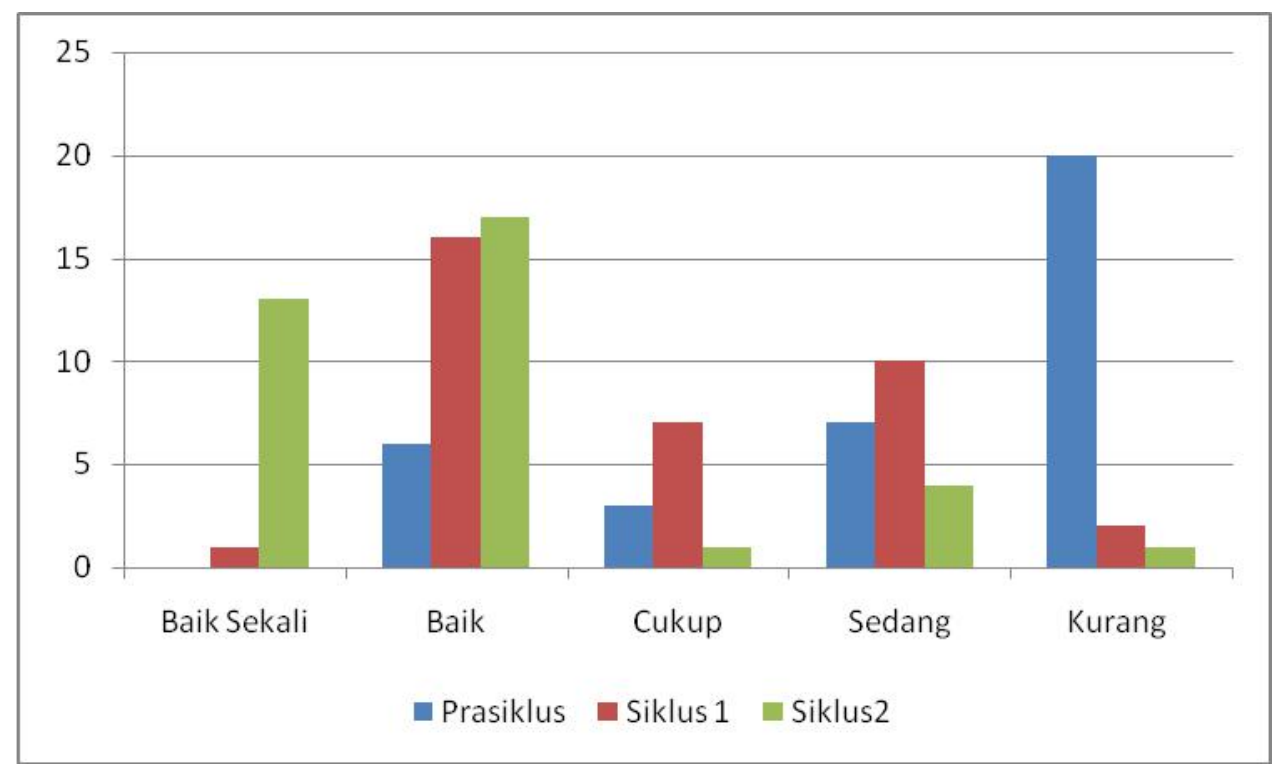

Grafik 2. Perbandingan Aktivitas dan Hasil Belajar Antara Prasiklus, Siklus 1 dan Siklus 2

\section{Pembahasan}

Hasil belajar matematika siswa meliputi rata-rata kelas, ketuntasan individual dan ketuntasan klasikal. Sedangkan aktivitas belajar siswa meliputi rata-rata aktivitas belajar siswa secara klasikal dan keaktivan siswa dalam mengikuti kegiatan pembelajaran. Berdasakan hasil observasi terhadap proses pembelajaran yang dilakukan pada siklus 1 tampak adanya peningkatan nilai rat-rata kelas dibandingkan dengan sebelum menerapkan pendekatan SAVI, peningkatan ketuntasan belajar secara klasikal maupun individual. Disamping itu juga diikuti peningkatan aktivitas belajar dibandingkan dengan sebelumnya. Meningkatnya aktivitas dan hasil belajar siswa dari siklus 1 ke siklus 2 menunjukkan terjadinya peningkatan terhadap pemahaman materi barisan dan deret. Hal ini menunjukkan bahwa pembelajaran dengan pendekatan SAVI mampu meningkatkan aktivitas dan hasil belajar matematika materi barisan dan deret. Berdasarkan hasil observasi yang dilaksanakan selama pelaksanaan pembelajaran menggunakan pendekatan SAVI menunjukkan adanya peningkatan aktivitas dan hasil belajar siswa, maupun kinerja guru dalam pembelajaran sebagai berikut:(a) terjadi peningkatan pencapaian ketuntasan belajar siswa bila dibandingkan dengan prasiklus 9 siswa (25\%) menjadi 24 siswa $(66,67 \%)$, dengan demikian sudah terjadi peningkatan sebanyak 15 siswa (41,67\%); (b) terjadi peningkatan pencapaian nilai rata-rata bila dibandingkan dengan prasiklus 57,11 menjadi 73,89, sehingga terjadi peningkatan sebesar 9,56; (c) terjadi peningkatan aktivitas siswa bila dibandingkan dengan prasiklus yaitu nilai rata-rata 1,86 (kurang) menjadi 3,11 (cukup), dengan demikian sudah terjadi peningkatan nilai rata-rata 1,25. Berdasarkan hasil pengamatan observer/peneliti terhadap kegiatan pembelajaran menunjukan bahwa: antusiasme dan rasa percaya diri, bersedia mencurahkan tenaga, waktu untuk mengembangkan diri siswa sudah tumbuh dengan sangat baik hal ini ditunjuk seluruh siswa berusaha untuk mengikuti dan mengerjakan tugas yang diberikan oleh guru; kemampuan 
bekerjasama dan berikhtiar secara produktif dengan orang lain ditunjukan tugas-tugas yang harus dikerjakan secara berkelompok dapat berjalan dengan baik. Pada siklus 1 guru belum bisa dikatakan berhasil karena walaupun terjadi peningkatan pencapaian ketuntasan belajar siswa bila dibandingkan dengan prasiklus 9 siswa (25\%) menjadi 24 siswa $(66,67 \%)$, dengan peningkatan ketuntasan sebanyak 15 siswa $(41,67 \%)$; namun belum mencapai batas ketuntasan ketuntasan yang ditetapkan pada indikator penelitian yaitu $85 \% \geq \mathrm{KKM}$ (70), maka dari itu guru masih memerlukan siklus selanjutnya yaitu siklus 2 dengan memperbaiki pembelajaran untuk mencapai batas ketuntasan klasikal yang telah ditetapkan.

Pada siklus 2 berdasarkan hasil observasi yang dilaksanakan selama pelaksanaan pembelajaran menggunakan pendekatan SAVI menunjukkan adanya peningkatan aktivitas dan hasil belajar matematikasiswa, maupun kinerja guru dalam pembelajaran sebagai berikut: (a) terjadi peningkatan pencapaian ketuntasan belajar siswa bila dibandingkan dengan siklus 1 yaitu 24 siswa $(66,67 \%)$ menjadi 31 siswa $(91,67 \%)$ sehingga sudah mencapai tingkat ketuntasan sebagaimana telah ditetapkan yaitu lebih besar atau sama dengan $85 \%$, terjadi peningkatan sebanyak 7 siswa $(25 \%)$; (b) terjadi peningkatan pencapaian nilai rata-rata bila dibandingkan dengan siklus 1 yaitu 73,81 menjadi 83,89, sehingga terjadi peningkatan 4,85; (c) terjadi peningkatan aktivitas siswa bila dibandingkan dengan siklus 1 yaitu nilai rata-rata 3,11 (cukup) menjadi 4,03 (baik), terjadi peningkatan nilai rata-rata 0,92 . Berdasarkan hasil pengamatan observer/peneliti terhadap kegiatan pembelajaran menunjukan bahwa: antusiasme dan rasa percaya diri, bersedia mencurahkan tenaga, waktu untuk mengembangkan diri siswa sudah tumbuh dengan sangat baik hal ini ditunjuk seluruh siswa berusaha untuk mengikuti dan mengerjakan tugas yang diberikan oleh guru; kemampuan bekerjasama dan berikhtiar secara produktif dengan orang lain hal ini ditunjukan tugas-tugas yang harus dikerjakan secara berkelompok dapat berjalan dengan baik; menyelesaikan tugas tepat waktu. Pada siklus 2 penelitian tindakan kelas ini sudah dapat dikatakan berhasil karena indikator ketercapaian aktivitas dan hasil belajar siswa sudah tercapai yaitu ketuntasan klasikal sebesar 85\% $\geq$ KKM (70), maka tidak diperlukan siklus berikutnya.

\section{Simpulan dan Saran}

Berdasarkan hasil penelitian tindakan kelas yang telah dilaksanakan dua siklus dengan penerapan pendekatan SAVI dalam pembelajaran matematika materi barisan dan deret bagi siswa kelas XI IPS1 SMA Negeri 1 Tawangsari semester 2 dapat meningkatkan aktivitas dan hasil belajar siswa. Hal ini dapat ditunjukkan dengan rata-rata banyaknya siswa yang mendapatkan nilai baik dari 1,86 ( kurang) menjadi 4,03 ( baik ). Ketuntasan klasikal mengalami peningkatan dari $25 \%$ menjadi $91,67 \% . \geq 85 \%$

\section{Daftar Rujukan}

Djamarah, Syaiful Bahri \& Aswin Zein. (2002). Strategi Belajar Mengajar. Jakarta: Rineka Cipta

Dimyati \& Mudjiono. (2006). Belajar dan Pembelajaran. Jakarta: Rineka Cipta

Faller, Klingmüller, \& Timmer. (2003). Simulation Methods for Optimal Experimental Design in Systems Biology, The Society for Modeling and Simulation International. 79 (12): 717-725 
H.B Sutopo. (2002). Metodologi Penelitian Kualitatif. Surakarta: UNS Press.

Lexy J. Moleong. (2009). Metodologi Penelitian Kualitatif. Bandung: Remaja Rosdakarya.

Lester \& Alice Crow. (1984). Educational Psychology. Surabaya: Bina Ilmu (diterjemahkan oleh: drs. Z. Kasijan)

Michael Komorek \& Reinders Duit. (2004). The teaching experiment as a powerful method to develop and evaluate teaching and learning sequences in the domain of nonlinear systems. International Journal of Science Education 26 (5): 619-633.

Muhibbin Syah. (1995). Psikologi Pendidikan dengan Pendekatan Baru. Bandung: Remaja Rosdakarya

Nana Sudjana. (1998). Dasar-dasar Proses Belajar. Bandung: Sinar Baru

Oemar Hamalik. (1990). Psikologi Belajar dan Mengajar. Bandung: Sinar Baru

Ricard. Jack C \& Theodore S. (1996). Appoach and Methode in Language Teaching. Cambridge Unevercity Press.

Sarwiji Suwandi. (2009). Penelitian Tindakan Kelas (PTK) dan Penulisan Karya Ilmiah. Surakarta : Panitia Sertifikasi Guru (PSG) Rayon 13 Surakarta.

Slavin. (1994). Cooperative Learning. Boston

Suharsimi Arikunto, Suhardjono \& Supardi. (2008). Penelitian Tindakan Kelas. Jakarta: Bumi Aksara.

W.S Winkel. 1986. Psikologi Pengajaran. Yogyakarta: Media Abadi

Suroso. (2016). Upaya Meningktkan Prestasi Belajar Matematika dengan Model Pembelajaran Auditory Intellctually Repetition ( AIR ). Jurnal Pendidikan, Volume 28, Nomor 3, November 2019, Hal: 255-264.

Hariyani Suprapti. (2019). Peningkatan Aktivitas dan Hasil Belajar IPA Materi Sistem Ekskresi

Manusia melalui Model Pembelajaran Discovery Learning dan Metode Eksperimen Siswa Kelas VIII G SMP Negeri 1 Boyolali pada Semester Genap Tahun Pelajaran 2018-2019. Jurnal Pendidikan, Volume 28, Nomor 3, November 2019, Hal: 339-352. 